University of Massachusetts Amherst

From the SelectedWorks of Robert Paynter

1992

1992 W.E.B. Du Bois and the Material World of African Americans in Great Barrington, Massachusetts

Robert Paynter 


\section{W.E.B. Du Bois and the Material World of African-Americans in Great Barrington, Massachusetts}

\section{Robert Paynter}

University of Massachusetts, Amherst

It is not uncommon for casual thinkers to assume that the United States of America is practically a continuation of English nationality . . . It is high time that this source of our thinking should be changed. America is conglomerate ... It represents peculiarly a coming together of the peoples of the world. (Du Bois, The Gift of Black Folk, 1924:i-ii)

Objects are related to social relations, ideologies and human beings in intricate and often contradictory ways. Teasing out these interconnections in the past and the present should be the task of archaeology. However, while focusing on the past, archaeologists often forget that objects are also signs within symbolic systems today. Historical archaeology's focus on African-American related objects has variously misidentified them, ignored them, identified them as products of an exotic culture, as markers of social distinctiveness, and as components in anti-racist arguments. These tacks are products of contemporary political and ideological struggles, and the objects and histories provide groundings for the next round of these debates.

The positioning of archaeological method and theory in the contemporary world frames the work done on the W.E.B. Du Bois Boyhood Homesite (Paynter 1990a). This paper considers how Du Bois' understanding of the relation between material culture and the rest of social life can inform historical archaeology, in particular, and archaeological anthropology in general. I begin with a brief description of the site, present some of the mobile objects from the site - the ceramics, glassware, metal, leather, etc. - and consider the intellectual tools offered by historical archaeology for analyzing these objects. A consideration of what Du Bois saw at the site, and how he used the connections between social relations

Critique of Anthropology (C) 1992 (SAGE, London, Newbury Park and New Delhi), Vol. 12(3): 277-291. 
and objects to construct vindicationist arguments provides a model for a politically contextualized, polysemic archaeological anthropology.

\section{The W.E.B. Du Bois boyhood homesite}

The site commemorating William Edward Burghardt Du Bois' life hardly reflects the historical significance of the man. Originally built and occupied in the early 1800 s by his maternal relatives - the Black Burghardts - and owned and occupied from then until the 1950s by relations of the Black Burghardts, it is today a poison ivy patch just off the road in the Berkshires of Western Massachusetts. In the summers of 1983 and 1984 the Summer Field School of the University of Massachusetts, Amherst's Department of Anthropology conducted preliminary archaeological surveys of the property to assess the extent and integrity of the archaeological remains. After surveying the site, remote sensing and subsurface testing concentrated on the area behind the house foundation to locate homelot features, such as trash pits, middens, privys, land-use data, and outbuildings.

Some of the major features recovered during the survey include the foundations for the house, a well to the southwest of the cellar hole, a plow zone in areas to the rear of the house, three trash pits, and two large middens. The middens, around fifty to one hundred square meters each, were surface collected and were the source of most of the 12,000 artifacts from site. One midden dates to the late nineteenth and early twentieth century when the site was occupied by the Wooster family; the other dates to $\mathrm{Du}$ Bois' use of the site in the second quarter of the twentieth century.

Objects from virtually every aspect of daily life are in the middens. There are architectural fragments of a house and a barn. There are objects from the external landscape - chicken and barbed wire. Stoves and pans for food preparation, plates, platters, glasses, cups and saucers for food service, and tin cans, bottles and crocks for food storage abound. Household furnishings include kerosene lamps, and inkwells; personal objects include shoes, after-shave lotion and patent medicine bottles. Some fragments related to agricultural production and transportation - horseshoes, headlights, etc. - are also found. Just the number and completeness of objects makes this site significant for understanding life in the Berkshires. That it is associated with Du Bois makes it even more important. And, Du Bois' writings, describing the lives of the northern African-Americans who created the site, make its interpretation fundamental for understanding the workings of the color line in the rural north. 


\section{Historical archaeology and the color line}

When I present these assemblages to historical archaeologists the most common question is: how does the material culture show how AfricanAmericans built, used and discarded these objects? Indeed, identifying a distinctive African-American material culture is one of the major endeavors of the discipline (e.g. Deetz 1977; Schuyler 1980; Singleton 1988; Singleton 1990; Ferguson 1991). Attributes of house construction and form (e.g. Vlach 1976; Deetz 1977; Jones 1985; McDaniel 1982), ceramic construction, form, and decoration (e.g. James 1989; Ferguson 1991; Armstrong 1985; Baker 1980; Shepard 1987; Leone and Crosby 1987), foodways (e.g. Deetz 1977), funerary rites (e.g. Cowan-Ricks 1991; Hall 1989), and agricultural landscapes (e.g. Holloway 1989; Wood 1974) have all been used to identify African-American material cultures.

These identifications rest on two approaches to the relationship of objects to the rest of life. One makes social identifications on the presence of traits characteristic of African cultures. So, for instance, Kwardata ceramic motifs, colonoware manufacture, house proxemics based on twelve foot modules, rice cultivation landscapes and baskets, are all seen as productions in North America based on underlying African material culture grammars (e.g. Brown and Cooper 1990; Deetz 1977; James 1989). The other theoretical position sees African-Americans using objects that have no necessary link to Africa, but using objects in combinations and forms that reflect the distinctive position of African-Americans in North America, as people distinctivly acting under the constraints of racial slavery and racial capitalism. Percentages of kinds of European ceramics, the use of low cost cuts of meat, or economical forms of meal preparation have thereby been used in interpreting African-American sites (e.g. Baker 1980; Deetz 1977; Schuyler 1980; Brown and Cooper 1990; Howson 1990 provides a thoughtful critique).

Preliminary examinations of the objects at the Du Bois site - using either theoretical strategy - fail to yield characteristics that archaeologists presently associate with African-American material culture. The house does not seem to conform to the hypothesized twelve foot module and is of a type similar to others scattered across the nineteenth century southern New England landscape. The glassware and ceramics are of the commercially available types, from Europe and the US, displaying no stylistic attributes as yet identified as distinctive of African-American use. Comparisons of foodways and trade patterns of these assemblages discloses similarities and differences with both African and EuroAmerican sites in the rural Northeast (Paynter et al. 1985; Stine 1990 
discusses similar ambiguities in the material record of early twentieth century sites in the rural US south). In short, no unequivocal AfricanAmerican signal exists in the material culture, at least as historical archaeology presently studies African-American material culture.

So, why has the history and historical archaeology of southern colonies and states yielded distinctive African-American material cultures and yet no such patterns are readily apparent at the Du Bois site? Numerous explanations, of historical interpretation and method, come to mind. One suggestion is that the small, dispersed African-American populations in the Northeast had neither the social organization nor the freedom in production to create distinctively African-inspired objects. Slaves lived in close contact with the masters and indentured white workers, were purchased for their domestic or agricultural labor, rather than for the products of their labor, and as a result, the material attributes of Africa though not the social institutions and meaning systems - disappeared early from the New England landscape and from cultural memory (Allen 1986; Cottrol 1982:13-36; Piersen 1988; Herskovits 1958; Greene 1942).

A point of disagreement is whether seventeenth and eighteenth century African-Americans developed a distinctive subculture and identity, with authors such as Cottrol (1982:13-36) arguing for a rather complete assimilation and Piersen (1988:143-160) arguing for a continuing cultural resistance based on African forms (especially sarcasm and political carnivals), though not based on attempts to establish institutional and/or economic autonomy. Most authors agree that nineteenth century industrialization, with the exclusion of African-Americans from the factory, led to greater segregation, which, in conjunction with a virulent white racism, resulted in separate African-American institutions.

Another theoretical position, from a semiotic perspective, emphasizes the distinctive role of objects in carrying signs of group identity, principally to mark and define social boundaries (Wobst 1977; Hodder 1979, 1982; Plog 1980). The semiotic role of material culture for marking boundaries in racially divided societies, where somatic rather than extrasomatic characteristics define identities, is poorly understood. If we keep in mind that using somatic characteristics, such as skin color, hair form, and facial configuration, to identify slaves was an ideology being invented in the seventeenth and eighteenth centuries (Drake 1987:13-42), then one has to explain why material culture would carry the same information. Such explanations will be hindered if there is an assumption that racial categories, marked by somatic attributes, will be congruent with ethnic categories, marked by extrasomatic traits. A rather different set of reasons for the apparent material cultural invisibility of the African-American 
population of the rural North concerns issues of bias. Very few AfricanAmerican sites have been investigated in the Northeast, generally, and we are still in a very preliminary stage of analysis at the Du Bois site. It may be that more studies, of this and other sites, will develop distinctive African-American patterns.

A final possibility, however, has to do with a different kind of bias. It seems reasonable that a white practitioner of a Eurocentric discipline would have a hard time decoding and understanding the ways of life of African-Americans living in Great Barrington over a century ago. Dicsiplines, such as archaeological anthropology, develop methods and theories that often support hegemonic ideologies. The problem of working outside these constraints is compounded by socialization when the practitioner is also of the elite group. However, there are often counterhegemonic perspectives to the dominant paradigm (e.g. Cole 1986; Drake 1987; Gwaltney 1980; Hymes 1972; Huizer and Mannheim 1979; Scott 1985; Valentine 1978), based on non-elite perspectives, that can be learned. Fortunately, I have a brilliant interlocutor, not only to the site, but also to the counter-hegemonic position of African-American scholarship-W.E.B. Du Bois.

\section{Du Bois and African-American material culture}

William Edward Burghardt Du Bois was born in Great Barrington, Massachusetts in 1868. The day after his death in Ghana in 1963, Roy Wilkins informed the 250,000 (Marable 1985:93) people assembled for the Civil Rights March on Washington 'that at the dawn of the twentieth century, [Du Bois'] was the voice calling you here today' (Lester 1971:147).

After graduating from high school in Great Barrington, Du Bois received a Bachelor's degree from Fisk, a BA, an MA, and a PhD degree from Harvard, and but for academic politics, would have received another doctorate from the University of Berlin (Du Bois 1968:146,149,175). His dissertation, The Suppression of the African Slave Trade to the United States of America, 1638-1870 (1896), is the first number in Harvard's Historical Studies series. Among his more than 20 books, The Philadelphia Negro (Du Bois 1899) is arguably the first work of urban ethnography in the United States. As a professor at Atlanta University he oversaw one of the earliest and most systematic studies of African-American lifeways resulting in fifteen volumes of the Proceedings of the Annual Conferences on the Negro Problem.

As if the scholarly output were not enough, Du Bois was a founder of the 
Niagara Movement, an important African-American organization for Civil Rights that eventually shaped the formation of and then merged into the National Association for the Advancement of Colored People. He served as the Director of Publications and Research for the NAACP from 1910 to 1934 and edited and frequently contributed to the Association's monthly, The Crisis, one of the most widely distributed publications by and about African-Americans in the early twentieth century. Du Bois' ideas on every topic touching the lives of African-Americans, from a description of the Alhambra in Spain to parables about racism, from critiques of Marcus Garvey to considerations of separation and Marxism in the struggle for Black liberation, were read by African-Americans throughout the land. By the end of his career, Du Bois had written innumerable pamphlets and articles, more than 10 scholarly books, major works of fiction, and two autobiographies (one in his 60s and one in his 90s) (Du Bois 1968; Lester 1971:55-113).

What did Du Bois see that was significantly African-American at the homesite? What things about the site stayed with him and were part of his African-American identity? In his autobiographies and writings about the site he recalls a song sung at his grandfather's fireside in the house we have been investigating. It was indecipherable to $\mathrm{Du}$ Bois, though it was attributed to his African great-great-grandfather's African mother or wife, 'a little black Bantu woman, who never became reconciled to this strange land' (Du Bois 1968:62). As transcribed in his autobiography:

Do bana coba-gene me, gene me,

Ben d' nuli, ben d' le-

An object of significance to Du Bois was his grandfather Othello's fire tongs.

Once my grandfather, and mayhap his, used them in the great fireplace of the House. Long years I have carried them tenderly over all the earth . . . But when the old fireplace rises again from the dead on Egremont Plain, its dead eyes shall see ... the real presence of these iron tongs resting again in fire worship in the House of the Black Burghardts. (Du Bois 1928:361)

It seems fair, given that this passage was written after $\mathrm{Du}$ Bois had composed The Pageant of Negro History (1913) and The Star of Ethiopia (1915), each with sections entitled 'The Gift of Iron', that these tongs represented a connection for Du Bois to his African as well as AfricanAmerican past.

Lastly, Du Bois describes the house.

I left the home as a child to live in town. . . . But for furtive glimpses I did not see the house again. . . . Then riding near on a chance journey I suddenly 
was homesick for that house. . . . From that day to this I desperately wanted to own that house for no earthly reason that sounded a bit like sense. It was 130 long miles from my work. It was decrepit almost beyond repair save that into its tough and sturdy timbers the Black Burghardts had built so much of their own dumb pluck that - "Why the stairs don't even creak!" said She, climbing gingerly aloft. (Du Bois 1928:361).

These things would undoubtedly escape the notice of most historical archaeologists. The song would have gone. The iron tongs, of considerable significance to Du Bois, are not unique to African-American sites. And the house, probably built by his maternal father's sister and her husband, appears to have no distinguishing stylistic features - rather it is the construction skills of his African-American ancestors that provide significance for Du Bois.

So, how does Du Bois see the material world of African-Americans? Du Bois looks for the connection between objects and the African-American experience, and then, defines their relationship to Euro-American material culture, society and ideology. Three kinds of objects are important to him - only the first of which is stressed by archaeologists. Of great significance are objects invented by and/or uniquely derived from African culture. Rice fields, Kwardata motifs, shotgun houses, colonoware vessels and other New World Africanisms investigated by archaeologists - these and other objects of African-American invention would all interest him (e.g. Brown and Cooper 1990; Deetz 1977; Ferguson 1991; see Philips 1989 for the presence of Africanisms in Euro-American culture and not in African-American culture). He also considers multivalent objects such as the iron tongs, objects that were invented, used and understood by African and Euro-Americans and yet that have distinctive meanings for peoples of African and European descent. The multivalency is rarely noted in material culture studies, which often only note the connection to EuroAmerican culture (cf. Brown and Cooper 1990; Garman 1992; Howson 1990, 1991; Upton 1985). And thirdly, he notes objects that were the result of African-American labor, which are rarely studied as informative about African-Americans (cf. Orser 1988, 1990, 1991).

Du Bois' appreciation of the broad impact of African-Americans on the material culture of North America went well beyond nostalgia, or the development of a sense of place, or his personal sense of identity. Indeed, objects figured in his more general intellectual program of making a vindicationist argument in response to white racism (Drake 1987:xvi-xxiii). Part of a familiar argument by Du Bois was to identify the 'Gifts' that people of African descent had given to world culture, in general, and to the United States in particular. These 'gifts', identified in his pageants (e.g. Du 
Bois 1913, 1915) and writings (e.g. Du Bois 1924), were material, social and spiritual. They included the gifts of iron, of bravery in battle, of the emancipation of democracy, of the freedom of womanhood, of music, art and literature, and so on.

The material gifts appear in two distinctive ways in his arguments. One was to call attention to African-American inventors, and thus to African and African-American creativity. Indeed, Du Bois saw the compilation of 350 patents held by African-Americans for the 1900 Paris Exposition, which he helped create and install, as a refutation of the racist belief of Black inferiority crystallized in a Massachusetts lawyer's statement that 'I never knew a negro to invent anything but lies' (cited in Du Bois 1900:576). In The Gift of Black Folk he calls attention to inventors, among others, the redoubtable Benjamin Bannekar; Jan Matzeliger, inventor of a revolutionary shoe-lasting machine; Elijah McCoy of automatic machinery lubricators; W.B. Purvis, inventor of a paper bag manufacturing machine; J.H and S. L. Dickenson, designers of devices for player pianos; and Granville T. Woods, holder of numerous patents for electrical communication devices. James' (1989) catalog and exhibition, 'The Real McCoy', extends this list to include among many others, Madame C.J. Walker and Massachusetts inventor, Lewis Temple, whose toggle-iron harpoon solved a major technological problem in the whaling industry and became 'the universal whale iron' (Ashley 1926:86; Kaplan 1953:85; see also Baker 1915; Kaplan 1955).

The second appearance of the material world is in Du Bois' recognition of the contributions of skilled and unskilled labor to the making of America. In The Gift of Black Folk he challenged the reader to 'think of the slave as a laborer, as one who furnished the original great labor force of the new world' (Du Bois 1924:52), on whose efforts and pain rested the staples that fed, clothed, drugged, and enriched the emerging bourgeoisie and working class of the industrial capitalist order-namely, tobacco, sugar, rice and cotton. In addition to the agricultural staples, this labor force was also responsible for the artisanry and craftsmanship that made the finer things of life, especially in the South. As he notes (quoting a correspondent) in the Atlanta University Publication on The Negro American Artisan 'One only needs to go down South and examine hundreds of old southern mansions, and splendid old church edifices, still intact, to be convinced of the fact of the cleverness of the Negro artisan, who constructed nine-tenths of them, and many of them still provoke the admiration of all who see them' (Du Bois and Dill 1912:35). And in the North, as in Philadelphia, it was the African-American caterer whose 'taste of hand and eye and palate set the fashion of the day' (Du Bois 1899:206; Bower and Rushing 1980). 
African-American sites - indeed most historical archaeological sites have objects invented by African-Americans. At the Du Bois site the most numerous of these are the mass produced shoes, some of which were undoubtedly made on Matzeliger's machines. However, though the material attributes of the 'inventions' associated with Wedgwood, Owens, or McKay are familiar to historical archaeology, the marks that Temple, or even Matzeliger, left on the material world have yet to be carefully identified and disseminated within the discipline. And, African-American sites indeed many historical archaeological sites - have objects built by AfricanAmericans. The Du Bois site itself - the house, barn, field, forests, well, and middens - constitutes the largest artifact of African-American construction. The history of the changing landscapes at the site, when seen from a Du Boisian perspective, chronicles how African-American men and women created lives along the changing class, color and gender line of Great Barrington (Paynter 1990b). The site today, through the efforts of members of the African-American community and their allies, is a National Register National Landmark site owned by the Commonwealth of Massachusetts. This affords it an important degree of protection. However, it is now an overgrown cellar hole in the woods - an all too appropriate metaphor for the state of the color line in late capitalist America.

\section{Conclusion}

So, what is an African-American material culture and what might be the contours of an archaeology that considered African-Americans? Most of the work in archaeology searches for Africanisms, thereby defining African-American material culture as something different from EuroAmerican culture (Orser 1990; Singleton 1988, 1990). Du Bois embraces the search for African inspired constructions. He adds objects of African as well as European derivation and objects that resulted from the labor of African-Americans, regardless of their stylistic characteristics, to his study of African-American material culture.

For Du Bois, all these African-American objects are gifts given to world culture. The choice of words is interesting, for the objects, actions and ideas $\mathrm{Du}$ Bois documents are not presented in his titles as 'achievements' or 'contributions.' 'Achievements' implies a standard that African-American creations are measured against - a practice that African-Americans were and still are submitted to using the narrow standards of hegemonic American culture. 'Contributions' suggest relations of redistribution, of tithing or taxing or giving-prestations at some world feast, again run by and for the benefit of the chiefly power centers of Euro-American culture. 
But 'gifts', as anthropology knows, are magical (Sahlins 1972; Mauss 1967). 'Gifts' simultaneously acknowledge and create social relations - and can be used to forge relations of equality. And 'gifts' speak volumes, demanding a recognition of the giver and requiring a return from the receiver. 'Gifts' are the media of politics among equals.

By writing a history of The Gift of Black Folk Du Bois is defining the terms of a cultural politics for our world (Epperson 1990; Fields 1990; Williams 1989:435,439). This politics starts by recognizing AfricanAmericans as creators and givers of social relations, ideas and material conditions. Euro-American culture should recognize its history's dependency upon these gifts. And with recognition it should be moved - in the spirit of the gift - and be generously forthcoming with returns. Historical archaeology should follow Du Bois' lead. It should use his wide definition of African-American material culture. And it should recognize the unavoidable cultural politics of doing archaeology. If we study the past to better inform people today of the creations by African-Americans that abound on the North American historical landscape, then historical archaeology can become a discipline that gives its findings back to our world in the service of a cultural politics that recognizes and values the diversity of its origins.

\section{ACKNOWLEDGEMENTS}

Many thanks to Nancy Muller for her continuing encouragement and inspiration. Linda Seidman of the Du Bois Archives, University of Massachusetts, Amherst always finds the gems; her efforts and interest are most appreciated. Maki Mandela, Ima McClaurin-Allen, and especially Helàn Page tolerated and improved my understandings of racial identities in stratified political economies. Thanks to Susan Hautaniemi for helping make sense of some of the 12,000 shards. And thanks to the students of the University of Massachusetts Summer Field Schools who deserve much of the credit for retrieving and organizing the material from the site. Thanks also to Rita Reinke, Rick Gumaer, Ellen Savulis, Ed Hood, Jim Garman, Mark Bograd, Uzi Baram, Mike Nassaney, Patricia Mangan, Sheila Brennan, Jim Delle, and Paul Mullins for their thoughts about the archaeology and geography of social inequality. Colleagues and friends John Bracey, Bill Strickland, Ernie Allen, Homer Meade and Bruce Laurie have helped me better see Du Bois' contributions to historical archaeology. Thanks, Linda.

\section{REFERENCES}

Allen, E., Jr (1986)

'Afro-American Identity: Reflections on the Pre-Civil Era', Contributions in Black Studies 7:45-93. 
Armstrong, D.V. (1985)

'An Afro-Jamaican Slave Settlement: Archaeological Investigation at Drax Hall', in T. Singleton (ed.) The Archaeology of Slavery and Plantation Life, pp. 261-287. Orlando, FL: Academic Press.

Ashley, C.W. (1926)

The Yankee Whaler. Boston, MA: Houghton-Mifflin.

Baker, H.E. (1915)

The Colored inventor. A Record of Fifty Years. New York: Amo Press, 1968.

Baker, V.G. (1980)

'Archaeological Visibility of Afro-American Culture: An Example from Black Lucy's Garden, Andover, Massachusetts', in R.L. Schuyler (ed.) Archaeological Perspectives on Ethnicity in America, pp. 29-37. Farmingdale, NY: Baywood.

Bower, B. A., and B. Rushing (1980)

'The African Meeting House: The Center for 19th Century Afro-American Community in Boston', in Robert L. Schuyler (ed.) Archaeological Perspectives on Ethnicity in America, pp. 69-75. Farmingdale, NY: Baywood.

Brown, K.L. and D.C. Cooper (1990)

'Structural Continuity in an African-American Slave and Tenant Community', Historical Archaeology 24(4): 7-19.

Cole, J.B., ed. (1986)

All American Women: Lines that Divide, Ties that Bind. New York: Free Press.

Cottrol, R.J. (1982)

The Afro-Yankees: Providence's Black Community in the Antebellum Era. Westport, CT: Greenwood Press.

Cowan-Ricks, C. (1991)

'African American Cemeteries: Historical Symbols'. Paper Prepared for the Annual Meeting of the American Anthropological Association, Chicago.

Deetz, J.F. (1977)

In Small Things Forgotten. New York: Anchor Press.

Drake, St-C. (1987)

Black Folk Here and There: An Essay in History and Anthropology, Vol. 1. University of California, Los Angeles: Center for Afro-American Studies.

Du Bois, W.E.B. (1899)

The Philadelphia Negro: A Social Study. Together with a Special Report on Domestic Service, by Isabel Eaton, Political Economy and Public Law XLV (University of Pennsylvania).

Du Bois, W.E.B. (1900)

'The American Negro at Paris', American Monthly Review of Reviews (Nov): 575-577.

Du Bois, W.E.B. (1913)

'Pageant of Negro History'. Amherst: MS on file, University of Massachusetts Archives, Du Bois Papers, Series 12, Folder No. 6119.

Du Bois, W.E.B. (1915)

'Star of Ethiopia'. Amherst: MS on file, University of Massachusetts Archives, Du Bois Papers, Series 12, Folder No. 6125. 
Du Bois, W.E.B. (1924)

The Gift of Black Folk: The Negroes in the Making of America. Boston, MA: Stratford.

Du Bois, W.E.B. (1928)

'The House of the Black Burghardts', The Crisis 35(4):133-134.

Du Bois, W.E.B. (1968)

The Autobiography of W.E.B. Du Bois: A Soliloquy on Viewing My Life from the last Decade of the First Century. New York: International Publishers.

Du Bois, W.E.B. and A. Dill (1912)

The Negro American Artisan. Atlanta University Publications, No. 17. Atlanta, GA: Atlanta University Press.

Epperson, T. (1990)

'Race and the Disciplines of the Plantation', Historical Archaeology 24(4):29-36.

Ferguson, L. (1991)

'Struggling with Pots in South Carolina', in R.H. McGuire and R. Paynter (eds) The Archaeology of Inequality, pp. 28-39. Oxford, UK: Basil Blackwell.

Fields, B.J. (1990)

'Slavery, Race and Ideology in the United States of America', New Left Review 181:95-118.

Garman, J. (1992)

' "Faithful and Loyal Servants": The Masking and Marking of Ethnicity in the Material Culture of Death.' Amherst: MA Thesis, Department of Anthropology, University of Massachusetts, Amherst.

Greene, L. (1942)

The Negro in Colonial New England, 1620-1776. New York: Columbia University Press.

Gwaltney, J.L. (1980)

Drylongso, A Self-Portrait of Black America. New York: Vintage.

Hall, R.L. (1989)

'African Religious Retentions in Forida', in J.E. Holloway (ed.) Africanisms in American Culture, pp. 98-118. Bloomington: Indiana University Press.

Herskovits, M. (1958)

The Myth of the Negro Past. Boston: Beacon Press.

Hodder, I. (1979)

'Economic and Social Stress and Material Culture Patterning', American Antiquity 44:446-454.

Hodder, I. (1982)

Symbols in Action. Cambridge: Cambridge University Press.

Holloway, J.E. (1989)

'The Origins of African-American Culture', in J.E. Holloway (ed.) Africanisms in American Culture, pp. 1-18. Bloomington: Indiana University Press. Howson, J. (1990)

'Social Relations and Material Culture: A Critique of the Archaeology of Plantation Slavery', Historical Archaeology 24(4):78-91. 
Howson, J. (1991)

'Analyzing Colonial Interpretations of Nineteenth-Century African West Indian Material Culture', Chicago, IL: Paper Presented at the Annual Meeting of the American Anthropological Association.

Huizer, G. and B. Mannheim, eds (1979)

The Politics of Anthropology: From Colonialism and Sexism toward a View from Below. The Hague, Netherlands: Mouton.

Hymes, D., ed. (1972)

Reinventing Anthropology. New York: Vintage.

James, P.P. (1989)

The Real McCoy: African-American Invention and Innovation, 1619-1930.

Washington, DC: Smithsonian Institution Press.

Jones, S. (1985)

'The African-American Tradition in Vernacular Architecture', in T. Singleton (ed.)

The Archaeology of Slavery and Plantation Life, pp. 195-214. Orlando, FL: Academic Press.

Kaplan, S. (1953)

'Lewis Temple and the Hunting of the Whale', New England Quarterly 26(1):79-88.

Kaplan, S. (1955)

'Jan Eamst Matzeliger and the Making of the Shoe', Joumal of Negro History 40(1):8-33.

Leone, M.P. and C.A. Crosby (1987)

'Epilogue: Middle-Range Theory in Historical Archaeology', in S. Spencer-Wood (ed.) Consumer Behavior in Historical Archaeology, pp. 397-410. New York: Plenum Press.

Lester, J., ed. (1971)

The Seventh Son: The Thought and Writings of W.E.B. Du Bois, Vols. 1 and 2. Edited with an Introduction by Julius Lester. New York: Vintage Books.

Marable, M. (1985)

Black American Politics: From the Washington Marches to Jesse Jackson. London: Verso.

Mauss, M. (1967)

The Gift. Translated by lan Cunnison. New York: W.W. Norton.

McDaniel, G.W. (1982)

Hearth and Home: Preserving a People's Culture. Philadelphia, PA: Temple University Press.

Orser, C. E., Jr (1988)

'Toward a Theory of Power for Historical Archaeology: Plantations and Space', in M.P. Leone and P.B. Potter Jr (eds) The Recovery of Meaning, pp. 313-343. Washington, DC: Smithsonian Institution.

Orser, C.E., Jr (1990)

'Historical Archaeology on Southem Plantations and Farms: Introduction', Historical Archaeology 24(4): 1-6.

Orser, C.E., Jr (1991)

'The Continued Patter of Dominance: Landlord and Tenant on the Postbellum 
Cotton Plantation', in R.H. McGuire and R. Paynter (eds) The Archaeology of Inequality, pp. 40-54. Oxford, UK: Basil Blackwell.

Paynter, R. (1990a)

'Afro-Americans in the Massachusetts Historical Landscape', in P. Gathercole and

D. Lowenthal (eds) The Politics of the Past, pp. 49-62. London: Unwin Hyman.

Paynter, R. (1990b 'The Transformations of the W.E.B. Du Bois Boyhood Homesite: A Consideration of Race, Class, Gender and Space.' Paper Prepared for the Annual Meeting of the Society for American Anthropology, Las Vegas, Nevada.

Paynter, R., M. Mensel, I. Minot, N. Perry, and C. Hyde (1985)

'Material Analyses of Economic and Racial Variation', Lake Placid, NY: Presented in the Symposium 'The Archaeology of Inequality' at the 25th Annual Meeting of the Northeast Anthropological Association.

Philips, J.E. (1989)

'The African Heritage of White America', in J.E. Holloway (ed.) Africanisms in American Culture, pp. 225-239. Bloomington: Indiana University Press.

Piersen, W.D. (1988)

Black Yankees. Amherst: University of Massachusetts Press.

Plog, S. (1980)

Stylistic Variation in Prehistoric Ceramics. Cambridge: Cambridge University Press.

Sahlins, M. (1972)

Stone Age Economics. Chicago: Aldine.

Schuyler, R.L., ed (1980)

Archaeological Perspectives on Ethnicity in America. Farmingdale, NY: Baywood.

Scott, J.C. (1985)

Weapons of the Weak: Everyday Forms of Peasant Resistance. New Haven, CT: Yale University Press.

Shepard, S.J. (1987)

'Status Variation in Antebellum Alexandria: An Archaeological Study of Ceramic Tableware', in S. Spencer-Wood (ed.) Consumer Choice in Historical Archaeology, pp. 163-198. New York: Plenum Press.

Singleton, T. (1988)

'An Archaeological Framework for Slavery and Emancipation, 1740-1880', in M.

P. Leone and P. B. Potter, Jr (eds) The Recovery of Meaning: Historical Archaeology in the Eastem United States, pp. 345-370. Washington, DC: Smithsonian institution.

Singleton, T.A. (1990)

'The Archaeology of the Plantation South: A Review of Approaches and Goals', Historical Archaeology 24(4): 70-77.

Stine, L.F. (1990)

'Social Inequality and Tum-of-the-Century Farmsteads: Issues of Class, Status, Ethnicity, and Race', Historical Archaeology 24(4): 37-49.

Upton, D. (1985)

'White and Black Landscapes in Eighteenth-Century Virginia', Places: A Quarterly Journal of Environmental Design 2(2): 59-72. 
Valentine, B. (1978) Hustling and Other Hard Work: Life Styles in the Ghetto. New York: Free Press.

Vlach, J. (1976)

'The Shotgun House: An African Architectural Legacy', Pioneer America 8:47-70. Williams, B.F. (1989)

'A Class Act: Anthropology and the Race to Nation Across Ethnic Terrain', Annual Review of Anthropology 18: 401-444.

Wobst, H.M. (1977)

'Stylistic Behavior and Information Exchange', in C. Cleland (ed.) For the Director, pp. 317-342. Museum of Anthropology, University of Michigan, Anthropological Papers 61.

Wood, P.H. (1974)

Black Majority: Negroes in Colonial South Carolina from 1670 through the Stono Rebellion. New York: W.W. Norton. 


\section{Rethinking}

\section{$\mathrm{MA}$ \\ ARX \\ XISI

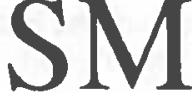

Sponsors an international conference...

\section{Marxism in the New World Order: Crises and Possibilities}

12-14 November 1992 (a) University of Massachusetts-Amherst

Étienne Balibar, Rosalyn Baxandall, Lourdes Beneria, Paul Bové, Paul Buhle, Joseph Buttigieg, James Crotty, Carmen Diana Deere, Gregory Elliott, Milton Fisk, Nancy Fraser, Wlad Godzich, Sandra Harding, Barbara Harlow, Nancy Hartsock, Michael Howard, Michael Lebowitz, Dominique Lecourt, Richard Levins, Richard Lewontin, Ernest Mandel, Manning Marable, Ellen MesserDavidow, Ralph Miliband, Warren Montag, Vicente Navarro, Bertell Ollman, Leo Panitch, Andrew Parker, James Petras, Mark Poster, Stephen Resnick, John Roemer, Andrew Ross, Sheila Rowbotham, Michael Ryan, Anne Showstack Sassoon, Marc Shell, Gayatri Chakravorty Spivak, Lise Vogel, Immanuel Wallerstein, Evan Watkins, Cornel West, Richard Wolff, Steffie Woolhandler And Many Others

\section{Art Exhibition}

This is My Body: This is My Blood Curated by Susan Jahoda and May Stevens

For information on registration, housing, daycare, etc., write to:

AESA, R M "New World Order" Conference

P.O. Box 715, Amherst, MA 01004-0715

Or (after August 1) Call: 413-545-3285

Pre-registration: $\$ 30$ three days, $\$ 20$ low income, $\$ 15$ one day On -site registration: $\$ 40$ three days, $\$ 30$ low income, $\$ 15$ one day

\section{a journal of economics, culture, and society}

For subscriptions to Rethinking MARXISM, call 1-800-365-7006 in New York, 1-212-431-9800 